\title{
A General Overview over Northern Cyprus Education Policies between 1983-2016
}

\author{
Hülya Ufuk, Çağda Kivanç Çağanağa \\ Institute of Graduate Studies and Research, European University of Lefke, Mersin, Turkey \\ Email: hufuk@eul.edu.tr, ckivanc@eul.edu.tr
}

How to cite this paper: Ufuk, $\mathrm{H}$. and Çağanağa, Ç.K. (2019) A General Overview over Northern Cyprus Education Policies between 1983-2016. Open Access Library Journal, 6: e4809.

https://doi.org/10.4236/oalib.1104809

Received: July 30, 2018

Accepted: July 23, 2019

Published: July 26, 2019

Copyright (๑) 2019 by authors and Open Access Library Inc.

This work is licensed under the Creative Commons Attribution International License (CC BY 4.0).

http://creativecommons.org/licenses/by/4.0/

\section{(c) (7) Open Access}

\begin{abstract}
The educational systems of the Northern Cyprus and the main frameworks of educational policies that changed depending on the changing governments between the years that have been set (1983-2016) as well as the human profile intended to be created in the 21st century have been discussed within the scope of this article. The research was conducted in a document analysis and screening model and as a result of the research, a specific framework for the general national education structure of Northern Cyprus and the stages that took place were intended to be established. When the research was conducted, the Northern Cyprus Ministry of National Education was contacted and the archival documents on the subject during the stages that were set were accessed. Then, the educational records were obtained from the Assembly of the Turkish Republic of Northern Cyprus and the main lines of the article were intended to be revealed by using the old archive resources.
\end{abstract}

\section{Subject Areas}

Education, History

\section{Keywords}

National Education Policies, Northern Cyprus Education System, 21st Century

\section{Introduction}

Education is among the most important factors for completing or developing the cultural dimension of a country. This is due to the reason that it is the citizens of the country who will take the country to the advanced level. In order to allow this, the citizens need qualified education, which refers to the lifelong learning strategy. It is among the highly important achievements that must be gained by 
the individuals to live in harmony with the society in which they live in and the world, to take part in the social development and to understand and to interpret the developments in the world. In addition, these achievements must be prepared to serve different segments of the education system. The fact that societies have a dynamic structure is directly proportional to the achievements of individuals, who form society, in terms of culture, art, science and citizenship. A student who knows the well-educated citizenship responsibilities can contribute more to the development of that country, and an individual who does not know the citizenship responsibilities cannot be expected to carry it out. Education policies must be introduced at this point. Educators conduct research on the issues of the acquirement of certain knowledge, skills and attitudes at certain ages and at certain education levels and produce projects. First of all, every country needs to have a planned educational policy. There should be leaders who do not only plan but also put the plans it into practice. Politics also has a very important role in education policies. Politicians need to plan studies improving learning and create a free and unique work environment for educational scientists. However, when the politicians create this, they follow policy according to their own ideologies. Politics has many parties within itself, and their views are divided into two as the "right view" and the "left view". While one view supporters have a more democratic, contemporary and future-oriented world view, the other view supporters have a conservative, nationalist and more reactionary view. For this reason, in a possible change of power, the Minister of Education of the country also changes; thus, the educational policies are shaped according to the minister's world view. The studies carried out on this issue also provide this result in general. This article discusses the issues of the general education system of the Turkish Republic of Northern Cyprus, the general and future aims of education and its educational policies. The Turkish Republic of Northern Cyprus is a republic established through a very long phase. In general, it can be seen that Cyprus has a variable education system. The Turkish Cypriot community education system has passed several stages. One of them is the integration with the Ottoman-Turkey education system. At this stage, the west-oriented education services were intended to be established through integration. The second stage consists of the time of giving priority to raising warriors of the 1950-1974 struggle periods by the report of the Turkish Affairs Commission. The third stage is the period of Education and Morality Commission. At this stage, efforts were made in order to raise the literacy rate and create a dynamic society. The fourth stage was called Serakinci (the Minister of Education at that time) restructuring period [1]. This structuring period still continues today. It has been intended to create a 21st century human profile. This article took in 1983, which is the official foundation date of the Turkish Republic of Northern Cyprus, as the beginning year. In the Turkish Republic of Northern Cyprus, the responsibility in the field of education and teaching belongs to the Ministry of Education in the name of the government. In this way, the education in North- 
ern Cyprus is shaped by the concept of "central administration". As a natural consequence of the fact that education and teaching are under the Ministry of National Education, it is seen that the education system in the Turkish Republic of Northern Cyprus has begun to be shaped according to the governmental power since 1983. The execution of different laws in the field of education depending on the governmental changes will be discussed in detailed in the following parts of this article. Before moving on to the articles of the Constitution, it would be beneficial to look at the human profile that Northern Cyprus (NC) intends to create in the 21 st century. The human profile intended to be created is the human:

1) who is based on social justice and rule of law,

2) who has the ability to think and to perceive,

3) who is prone to use of information and technology,

4) who does not avoid to become self-evident,

5) who knows how to access the information,

6) who can design and create,

7) who is open to change,

8) who has a cultural of reconciliation,

9) who can say freely and who can think freely,

10) and who has environmental consciousness [2].

The NC Constitution expresses the right to learn in order to better understand the significance of the education in the $\mathrm{NC}$ as follows:

1) Every citizen has the right to education and teaching without any discrimination, and no one shall be deprived of the right to education and teaching.

2) All kinds of teaching and educational activities are free under the governmental supervision and control.

3) Education and teaching places contrary to the contemporary science and education principles cannot be opened.

4) Providing public education and training needs are the primary tasks of the state, the state shall carry out this task in a planned manner in line with Ataturk's Principles and Revolutions, in accordance with the national culture and spiritual values, in order to ensure the development of the age and technology, and to respond to the demands and needs of the community and the society.

5) Every child has the right to compulsory education up to the age of fifteen and to free education up to the age of eighteen without discrimination.

6) Necessary precautions should be taken in order to raise students with special educational needs both inside and outside the school due to the conditions to become beneficial for the society.

7) Successful students lacking financial means must be provided with the necessary assistance through scholarships or other means in order to ensure that they reach the highest education level.

8) No person, family or class privilege should be recognized in education [3]. 
As a result of all the efforts put forward in spite of all these legislative acts, the aim of the national education system of the Turkish Republic of Northern Cyprus needs to be restructured in order to take place among other societies in the age of information, to develop social, economic and cultural environment, to provide opportunity equalization in education, life-long, open-change and student-centred education.

The topics in the following parts of the article have been listed respectively as follows; basic principles of national education, basic structure of national education, the governments established in Northern Cyprus between 1983 and 2016, the government programs that each government produces in its own ideology when it comes to its successor, the ministers of education respectively, the performed education plan studies, the development plans of the NC, educational organizations, the general structure of the NC Ministry of Education and Culture, non-formal education situation in the NC, pre-2005 education structuring, the position of the country in the education field after the structuring in post-2005, 21st century human profiles intended to be created in Northern Cyprus and the possible educational structure to be implemented in Northern $\mathrm{Cy}$ prus [3].

\section{Historical Development of Turkish Cypriot Education System}

Under this title, education in the Ottoman period, education in the British period, education in the Republic of Cyprus, education in the Federated State and education in the NC period will be examined.

1) Education in the Ottoman Period:

After the Ottomans conquered the island of Cyprus, they changed the structure of the island in line with their own policies. The Ottomans carried their own education systems to the island, which was based on religion. No centralized schooling has been observed in Cyprus during the Ottoman period. Schools were usually built near mosques and the Qur'an teaching formed the basis of the curriculum. Teachers were educated at madras as according to religious education. The appointment of the teachers was performed by the Sharia Council. Since there was not a certain class and desk arrangement in this period, the students were educated by putting mats around.

\section{2) Education in the British Period:}

In 1878, the British took the island of Cyprus from the Ottoman government and turned it into its own colony. They made major changes politically, culturally and economically in Cyprus during a period of 82 years. Until 1924, they maintained the education system of the Ottoman Empire and formed a committee called "Council of Education" in order to be responsible only for their teaching activities. After 1929, they intended to establish and integrate the concepts of "democracy" and "secularism" into education. The greatest contribution to education in the British period was the pedagogical approach to schools and the su- 
pervision of inspectors.

\section{3) Education in the Republic of Cyprus period:}

The Republic of Cyprus was established in 1960. After this date, the island has become a bi-communal island. The education work was transferred to the “Turkish Department of Education". The conflicts of 1963, which started between the two communities in the bi-communal island, adversely affected the education of the Turkish community and students started to leave their schools in this distrust environment. The most important practice in the field of education in this period was the formation of a new curriculum and the implementation of "science" and "social studies" lessons. In addition, the Cyprus Turkish Teachers' Trade Union was established in this period.

4) Education in the Federated State and Turkish Republic of Northern Cyprus:

New decisions were taken regarding education during this period. It was accepted that education was free and compulsory. In 1977, the law on the transfer of teachers was accepted.

NC was proclaimed on the 15th November 1983. After the proclamation of the NC, many important developments took place in the field of education.

- On 23 May 1986, the "National Education Act" was approved by the parliament. Following this act, education has become compulsory until fifteen years old starting from pre-primary education.

- In 1986, the sixth grade was abolished at primary schools with the aim of adapting to Turkey.

- In 1988, "Law on Apprenticeship and Vocational Training" entered into force.

- In 1989, “Turkish Teacher's College” was taken to the level of four-year college.

- In 1991 religious ceremonial days (Kandil) and Thursday afternoon teaching hours were abolished.

- The centralisation project was implemented in 1995.

During this period, the situation in schools was as follows:

a) In the academic year 1991-1992, 20 Temmuz Science High School accepted its first students by conducting an exam.

b) In 1999, Bülent Ecevit Anatolian High School was opened.

c) In 1990-1991, High School of Fine Arts was opened.

d) In the 2005-2006 academic year, the preparatory classes started to be called "9th grade".

e) In 1982-1983, Open Education Faculty started its education and learning.

f) In 1990-1991, European University of Lefke and Girne American University were established.

g) In 1997-1998, Cyprus International University was established.

h) In 2006-2007, the Kalkanli campus of Middle East Technical University was opened. 
Despite all these breakthroughs, the education system has a base of memorisation and the students adopted the characters that do not think and question. Contemporary technologies could not manage to enter schools and disruptions were experienced in terms of administrative structure.

\section{General Structure of the National Education System}

It can be seen that the system is divided into formal education and non-formal education.

Formal education:

1) Pre-school education

2) Primary education

3) Secondary education

4) Higher education

5) Special education

Non-formal education: includes institutions apart from special education. In general, it covers courses for various purposes. These courses include reading and writing courses, craft courses, etc.

\subsection{General Objectives and Basic Principles of National Education}

\section{General Objectives:}

1) Raising citizens of the Turkish nation who are bound to Ataturk's principles and revolutions and who aim to modernize, and citizens who are dependent on the principles of democracy, social justice and rule of law.

2) Raising citizens who know the realities underlying the struggle for existence, who are linked to this struggle from the heart and who know their responsibilities strongly linked to their homeland Turkey and their own country.

3) Raising creative and productive citizens balanced in terms of body, mind, morality, emotion, with a robust character, having a scientific mind and a broad world view, holding their own interests above the interests of the community and carefully protecting the state.

4) Equipping individuals with the knowledge and skills to develop their interests and skills, preparing them for life, contributing to the development of the community and raising individuals who will endeavour in this direction [4].

The Basic Principles:

1) Generality and equality

2) Community needs and individual skills

3) Orientation, training and success

4) The right to compulsory education and teaching

5) Equality of opportunity and possibility

6) Continuity

7) Education at all places

8) Co-education

9) Science and environmentalism 
10) Planning

11) Ataturk's Principles and Revolutions and Ataturk's Nationalism

12) Development of national ethics and culture

13) Teaching Turkish and foreign languages

14) Secularism and religious education

15) Development of democracy consciousness

16) Collaboration between school and family

17) Compatibility

18) Conducting educational activities [3].

\subsection{Organization of Education in the Turkish Republic of Northern Cyprus}

${ }^{1}$ The Ministry is responsible for supervision and inspection of education and teaching services in the name of the state.

The Turkish Cypriot Education System is inspected through the understanding of centralised governance.

No educational activities shall be conducted contrary to the general objectives and basic principles of the Turkish Cypriot National Education and this act and no educational institution shall be established contrary to the principles of modern science.

\subsection{Education Planning in the Turkish Republic of Northern Cyprus}

In NC, the planning within the scope of the Ministry of National Education (MoE) is performed in cooperation with the State Planning Organization (SPO) and the Ministry of National Education and Culture. Educational objectives are addressed in the high planning committee. It is then published in the official gazette after being discussed in the Council of Ministers [3].

The education planning has been defined in the National Education Act as follows:

- The development of the Turkish Cypriot National Education is planned and carried out in accordance with the economic, social and cultural development objectives and with regard to education-human power-employment relations. The relevant planning and realization activities are carried out in cooperation and coordination with the Ministry and related institutions and organizations [3].

\section{Development Plans in the Turkish Republic of Northern Cyprus and Outlines of National Education Councils}

\subsection{Development Plans}

Three five-year development plans have been made in the Northern Cyprus so far.

${ }^{1}$ Article 68 depicted in the Execution, Supervision and Inspection section of National Education Law No. 40/1992. 
1) The First Five-Year Development Plan (1978-1982)

2) The Second Five-Year Development Plan (1988-1992)

3) The Third Five-Year Development Plan (1993-1997)

After the last development plan, no development plans were made in the NC, but rather it was seen that there were bilateral agreements with the Republic of Turkey [2].

Since the first five-year development plan is not the main subject of the article, the secondary and tertiary development plans will be focused primarily.

The main objective of the development plans is to provide common basic education to all citizens and to train qualified human power.

The targets and policies with the second five-year development plan: improving the pre-school education through the opening of the nursery schools and nursery classes, increasing the schooling rate of primary and secondary schools, encouraging high school students to go into vocational high schools and increasing the scope of higher education are among the targets to gain students. Policies have been developed in order to achieve these goals. The general outlines of the policies of the second five-year development plan were as follows:

- Life-long learning

- Enabling individuals to question the content of the lessons

- Freedom of thought and developing democratic understanding in the individual

- Changing the parrot fashion in education

- Improving the efficiency of in-service training

- Increasing the non-formal education opportunities.

Policies targeted by the third five-year development plan: dissemination of the nursery school implementation and including the 5-year-old group within this arrangement, centralization of elementary schools in small settlements and encouraging students for higher education are among the goals of this development plan. The policies improved accordingly are as follows:

- Research-oriented education

- Meeting the educational needs of children in need of special education

- The development of Maarif Colleges in order to provide contemporary education

- Guiding young people to a profession at the end of compulsory education.

\subsection{National Education Councils}

The general objective of councils: The Councils serve to provide reflective and guiding advice to the Minister and the Council of Ministers in determining the basic policies to be followed in education and teaching and in determining the measures regarding putting into practice taking into account the changing needs of society and individuals in contemporary developments in science and technology [3].

A total of five National Education Councils have been organized in Northern 
Cyprus until now.

1) National Education Council (20-25 October 1975);

2) National Education Council (17-21 June 1991);

3) National Education Council (19-30 June 1995);

4) National Education Council (24-26 March 2005);

5) National Education Council (10-14 March 2014).

The general contents of all of the national education councils are as follows:

They regard pre-school education as a very important step for education. Therefore, they have a high-level of interest into pre-school education. Among the primary goals is to transform the nursery classes into a separate nursery school separated from the primary schools, which refers to creating a separate unit. This educational phase is more suitable for children from forty-eight-month to seventy-two-month old. As a natural consequence of too much interest in this area, priority is given to the training of teacher candidates, to the establishment of separate pre-school departments in teachers' academies in order to train specialist teachers in this area and to the preparation of educational programs based on science. The supervision of these nursery schools by the Ministry, ensuring that school buildings do not pose harm regarding the health conditions, ensuring that the educational arrangements in the classroom are complete, the number of students in the classroom and the avoidance of students' personalities from harmful behaviour have been seen as important factors and decisions were taken on this point (Decisions of the Preschool Education Commission, 1999). The primary school step as the first step of education has also been seen as an important step similar to the pre-school step. Therefore, decisions taken in these two fields generally appear to be similar. The issues emphasized in the national education councils, which differ from the pre-school councils, usually are the provision of equal opportunities among students, the teaching of environmental awareness, the opening of guidance services in primary schools and the application of contemporary disciplinary rules. Secondary education was focused in the Council decisions. This was because it is the education period of the generation that will establish the future of the country. Pupils get into a four-year secondary education process after primary school education. In this way, pupils are encouraged to the vocational training. Thus, all the performed exams are to determine the student levels. Students are entitled to high school education by taking the diplomas in which their levels are determined after completing the four-year secondary schooling period. In high school education, all courses are compulsory in the first year of high school. Councils focus on the issue that students should have the right to choose a branch when passing the second year of high school after the first year of high school. In line with proceeding towards vocational fields, it is considered that students would be more productive if their lessons were in line their interests. However, another emphasized issue is that thinking, researching, questioning and reasoning lessons would be compulsory even though they choose their optional lessons from their fields of speciality. This is because there is a need to create inquisitive and researcher people among 
the human profile intended to be created. For this reason, it is given a separate attention to this issue. A variety of books approved by the Board of Education are offered instead of a single book implementation [3].

Special education and vocational technical education were also focused on the decisions of the National Education Council. Regarding special education, the decisions focused on the facts that "reinforced education" should be applied to students with special education, the necessary tools and equipment they need should be provided, a separate unit linked to this Ministry should be established and the extent to which students have fallen behind in what areas should be identified. It was emphasized that it is necessary that the Ministry should further expand their budgets on the field of vocational and technical matters, the programs applied in vocational and technical education should be planned in such a way as to bring diplomas and various certifications according to international standards [3].

Objectives of basic education as a result of National Education Councils:

To switch to a student-centred education system, to raise individuals who know how to cope with problems in the moral direction, who can work in teams, who have a critical literacy rate, who understand life-long education, who can lead their own life freely, who can realize their own potentials, who recognize their own cultures and who approach different cultures with interest and tolerance. Similar to this definition, constructivist education is supported by [5] in exploring and analysing knowledge, developing the information and thinking process, and integrating new experiences with past experiences [5].

After the taken Council decisions, a restructuring of the education system was found necessary by the Basic Education Commission. The implications put forward in this regard are as follows:

- The possibility for the Turkish Cypriot community to take its place among other societies in the information age

- Social, cultural and economic development

- Having an education system open to change

- It is deemed necessary for the purpose of enabling individuality in education.

The human profile intended to be created as prescribed by the new education system in the Basic Education Commission Decisions: Peaceful citizens who are based on the rule of law, who possess problem solving skills, who can use knowledge creatively, who are prone to technology use and open to change, who have the power of designing and creativity, who are equipped with working area, who have a culture of mediation, who developed empathy sensation, who respect human rights and natural rights, who know Cyprus as homeland, who have good relations with Turkey and other neighbouring individuals and who know how to protect individual and social rights [5].

\section{1983-2016 Government Programs}

\section{Educational Objectives}


Constituent Assembly Government Program (13-12-1983/19-07-1985) Minister of National Education, Culture, Youth and Sports: Orhan Zihni

\section{Bilgehan}

$>$ To educate citizens, in the education of the Turkish Cypriots of Northern Cyprus and in all educational activities, who stick to Atatürk's principles, Turkish nationalism and cultural values and who are aware of their responsibilities towards their country, society and government, to make younger generations have a life and get a profession

$>$ To equip them with contemporary educational opportunities by giving importance to quantity and quality

$>$ To educate students as researchers

$>$ To provide them with opportunities to learn by doing and experiencing

$>$ To give importance to the dissemination of pre-school education

To ensure that all textbooks are arranged with the realities of the country

$>$ To develop existing higher education institutions

$>$ To adopt the Turkish culture without corruption and to ensure the continuity of cultural ties with the Motherland Turkey [6].

\section{UBP-TKP Government Program (19-07-1985/2-09-1986)}

\section{Minister of National Education, Youth and Sports: Salih Coşar}

Atatürk's principles shall continue to be the basis of the national education. Atatürk's principles shall contribute to the adoption of the consolidated national consciousness.

Equal opportunities and facilities shall be expanded

$>$ We shall open our own universities

$>$ Non-formal education shall be considered important

Vocational and technical education shall be focused

$>$ New arrangements shall be made in in-service training

$>$ Sports facilities shall be developed

$>$ It shall be paid attention to raise intellectual and Kemalist religious functionaries [5].

\section{UBP-YDP-Government Program (2-09-1985/23-05-1988)}

\section{Minister of National Education and Culture Salih Coșar}

Ataturk nationalism shall be spread among all citizens

$>$ Citizens who know their responsibilities towards the motherland Turkey shall be raised

Schooling rate shall be increased in primary and secondary schools

A job classification and title arrangement shall be made

> Foreign language education shall be taken to forefront. The number of Turkish Maarif Colleges shall be increased in line with this objective.

> It shall be ensured that Eastern Mediterranean University will be developed

Working conditions and personal rights of teachers shall be improved

Arts and culture studies shall be increased [5].

UBP-Government of Independents (23-05-1988/20-06-1990) 


\section{Minister of National Education and Culture Salih Coșar}

To raise the citizens under the Atatürk Nationalism

To create a sense of loyalty to the Motherland Turkey

$>$ To provide equality of opportunity with compulsory and free education until the age of 15

To meet the needs of students who need special education

$>$ To create effective and efficient textbooks for foreign language education

To use the latest technologies in all schools

Do bring Eastern Mediterranean University to the highest capacity

> Motherland Turkey and the NC shall be focused on strengthening existing cultural ties and cooperation in education, culture and art [5].

\section{UBP Government (20-06-1990/12-01-1994)}

\section{Minister of National Education and Culture Eșber Serakınc1}

To raise the citizens under the Atatürk Nationalism

$>$ To create a sense of loyalty to the Motherland Turkey

> Providing educational opportunities for students to research

$>$ Promoting pre-school education

Increasing the emphasis on special education

Instilling patriotism and national feelings to students

$>$ Providing a safe future for students

$>$ Producing definitive solutions to youth problems

$>$ Increasing the importance given to sports activities [5].

\section{DP-CTP Government (12-01-1994/22-05-1995)}

\section{Minister of National Education and Culture Mehmet Ali Talat}

> Raising secular, contemporary, human worthy individuals abiding by Ataturk's principles

Instilling free thought, democracy, national and universal values to students

D Educating students capable of being respected in the world

$>$ The education budget shall be increased

New school buildings shall be built

Arrangements shall be done in the Ministry of National Education

Schools shall increase its capacity to serve for a full day

Working conditions of teachers shall be improved

A special education unit shall be established within the Ministry

$>$ Nursery schools shall be separated from primary education

Small village schools shall be centralized

Regulation of 'Subject Teachers' shall be issued

$>$ The number of students shall be in accordance with the contemporary educational order

> Curriculum programs shall be organized Environment, health, traffic, tourism and sexual education shall be provided to students

$>$ Entrance regulations for colleges shall be arranged

The autonomy of universities shall be protected 
Importance given to culture and the arts shall be improved

National archive shall be developed

D Republic of Turkey and the Turkish Republic of Northern Cyprus shall be based on a healthy basis for relations in the fields of education, science, art and culture

Youth shall be instilled patriotism

Brain drain shall be intended to be prevented

$>$ The condition of youth centres shall be reviewed

A folk dance association shall be established with the aim of unity and solidarity

Physical Education Department of Sports regulations shall be arranged in accordance with the conditions of the day [5].

CTP-DP Government (22-05-1995) - (11-12-1995) Minister of National

Education and Culture: Mehmet Ali Talat

CTP-DP Government (11-12-1995/28-08-1996) Minister of National

Education and Culture: Ahmet Derya

$>$ Raising contemporary secular and nature-loving people

$>$ Raising reputable humans recognized in the qualified world

$>$ Expanding the education budget

$>$ Building new school buildings and lodgings

Improvement in in-service training

$>$ Bringing full-time education to schools

Putting the EMU law into effect

D Teachers' working conditions shall be improved

$>$ The number of classes shall be issued to the contemporary level

An increased emphasis on special education shall be implemented

$>$ Eight-year education period shall be addressed holistically

> Work shall be conducted in order to increase the compulsory education from fifteen years to eighteen years

$>$ Village women courses shall be started

$>$ A state symphony orchestra shall be created in order to expand the field of culture

$>$ Regional cultural centres, archives and libraries shall be developed

> The computer network shall be developed between the Ministry and schools

$>$ The necessary arrangements shall be made for the third national education forum [5].

UBP-DP Government Program

(28-08-1996/16-09-1998)

Minister of National Education, Youth and Sports: Günay Caymaz

(16-09-1998/30-12-1998)

Minister of National Education, Youth and Sports: Erol Özçelik

(30-12-1998/08-06-2001)

Minister of National Education and Culture Mehmet Altinay

It was intended to provide individuals with mental, physical, spiritual com- 
petence

$>$ Raising generations that value science and art with rational, researcher, participant, innovative, revolutioniser creative thinking

$>$ Opportunities for learning by living shall be increased for students

$>$ Individual equality shall be provided in education

$>$ Trade-tourism vocational high schools shall be developed

$>$ Maarif college program shall be re-evaluated

Apprenticeship and vocational education law shall be implemented to those who cannot continue their education after compulsory education

Small schools shall be centralised

A reconciliation shall be established between the school-family unions and teachers' unions

The duration of pre-school education shall be increased

Ataturk Teachers Academy laws shall be re-prepared

$>$ Collaboration between Higher Education Council and the NC [7].

UBP-DP Government Program (08-06-2001/13-01-2004) Minister of National Education and Culture Ilkay Kamil

Raising generations loyal to Atatürk's principles

Lifelong learning strategies shall be developed

$>$ The lack of academic staff shall be considered and taken into account

$>$ The modernisation in education project shall be implemented

$>$ A more democratic environment shall be created for the development of art [5].

\section{CTP-DP Government Program (13-01-2004/26-04-2005)} Minister of National Education and Culture Erbil Akbil

Individuals loyal to Atatürk's principles shall be raised

Importance shall be given to scientific studies

$>$ Importance shall be given to foreign language education

$>$ Student councils shall be formed

$>$ Buildings shall be repaired

Vocational colleges shall be opened to cover the lack of intermediate staff

Culture and Art Advisory Board shall be established

Textbooks including local information shall be prepared

$>$ Daily and annual study programs in education shall be prepared

$>$ New higher education law shall be drafted for democratic understanding

An integration project in special education shall be developed

$>$ Children shall be given to guidance for support

Alternative approaches to exams shall be introduced, a student-centred system, which takes into account skills and interests rather than race and screening systems, shall be adopted

Optional lessons shall be added to the compulsory lessons

$>$ Students shall acquire the habit of reading books

A foreign language shall be provided besides English 
Students shall be prepared for GCE examinations to prepare for third world countries

The curriculum shall be made contemporary to be free from obsolete details. Textbooks including local information shall be studied in the classroom

Audio-visual education shall be implemented

Importance shall be given to the promotion of teachers

Education programs shall be modernized

> Parent-teacher associations shall be made more effective

Importance shall be given to life-long learning [5].

CTP-DP Government (26-04-2006/04-05-2009) Minister of National Education and Culture Canan Öztoprak

Education based on production and equal opportunity, in accordance with the occupational standards of the market, which provide effective guidance services to students in accessing information and which allow horizontal and vertical transitions

$>$ Education emphasizing the concepts of freedom, democracy and social justice [5].

UBP Government (11-05-2009/27-05-2010)

Minister of National Education, Youth and Sports: Kemal Dürüst

To raise rational, creative, innovative, contemporary individuals

$>$ Equality and generality in education

$>$ Commitment to the Motherland Turkey

$>$ Secondary schools of colleges shall be reopened

Education shall be conducted on the interests and abilities of the students

Religious education opportunities shall be provided to students other than formal education

History books shall be re-evaluated

> Teachers' Academy diplomas shall be reorganized according to Turkish standards [5].

\section{UBP Government}

(27-05-2010/16-04-2011)

Minister of National Education, Youth and Sports: Nazım Çavuş̧oğlu

(17-04-2011/07-09-2012)

Minister of National Education, Youth and Sports: Kemal Dürüst

(11-09-2012/13-06-2013)

Minister of National Education, Youth and Sports: Mutlu Atasayan

Life-long learning has been prioritized

Ataturk's thought system was brought to the forefront as usual

Education portal shall be created

(NC Assembly of the Republic, 2016)

CTP-BG, DP-UG Government

(13-06-2013/31-08-2013)

Minister of National Education, Youth and Sports: Asım Iddris 


\section{(31-08-2013/24-09-2013)}

\section{Minister of National Education: Prof. Mustafa Arabacioğlu}

(24-09-2013/15-07-2015)

\section{Minister of National Education: Prof. Özdemir Berova}

> School-based management and school-based budget approach shall be implemented

$>$ The 0 - 3 age group shall be under control in the field of education programs

Special education law shall be issued

College entrance systems shall be organized

$>$ Multi-program high schools shall be opened

Multi-program high schools shall be opened

D Curricula shall be prepared with the contributions of academicians and education specialists

Cyprus History books shall be regularly improved [5].

UBP-DP Government (22-04-2016)

\section{Minister of National Education: Prof. Özdemir Berova}

Education shall be based on scientific evidence

> School management boards shall be established

> Infrastructure studies shall be started in order to start full-time education

> The Department of Board of Education shall be transformed into the chair of the Board of Education and a "research and development unit" and an "assessment-evaluation unit" shall be established

> Preliminary work shall be completed for the establishment of distance learning education

Private schools and public schools shall be inspected at the same rate [5].

\section{Results and Recommendations}

Consequently, the NC National Education system has been undergoing various changes within the specified years. Our national education system has been continuously intended to be brought to the level of contemporary education since the establishment of the NC in 1983, but its level of success is still being discussed. It is observed that the implemented development policies did not continue after 2005. It has been determined that educational agreements have been made in terms of bilateral relations with the motherland Turkey instead of making a development policy. The alignment process between the European Union and the NC has begun since 2005 onwards. However, consequently, the NC Ministry of National Education does not make much contribution to the country during this alignment process. One of the examples is the Erasmus scheme. The Erasmus program encourages international cooperation among universities and aims to achieve mutual exchange of students and educators in Europe and contribute to the development of academic recognition and transparency of the studies in the countries participating in the program [8]. This program is implemented in the Republic of Turkey but not in the NC. 
It has been observed that the institutionalization of the educational plans of the NC is necessary. The necessity of overcoming traditional political and bureaucratic practices must be considered in order to achieve this. Flexible education plans, which collects continuous data, measures the effectiveness of the implemented programs, is broad-based, explores the future, does not contain detailed details and is constantly updated, should be prepared instead of central planning strategies while the Turkish Cypriot education system is being re-evaluated [8]. The NC also faces economic difficulties due to political non-recognition. This is the reason why it is considered necessary for the Republic of Turkey to use the investment expenditures made for the development of higher education in pre-school and other stages of education for a certain period of time.

\section{Conflicts of Interest}

The authors declare no conflicts of interest regarding the publication of this paper.

\section{References}

[1] Aytekin, H. (1993) Northern Cyprus, Structural Transformation in Education System, Nicosia.

[2] Educational Model of Cyprus in 2000s, 2000, Turkish Cypriot Teachers Union Publications, Nicosia.

[3] Nesim, A. (1987) Our Education Suns Which Do Not Set, Research on Turkish Cypriot Education, Nicosia.

[4] Reis, O. and Çağlar, M. (2007) Contemporary and Regional Education Planning in the Process of Paradigm Transformations in Education, Pegem, Ankara.

[5] Northern Cyprus. Government Programs in Northern Cyprus (1983-2016).

[6] Basic Education Commission Decisions (1983-2016). http://www.mahkemeler.net/birlestirilmis/33-2017.docx

[7] National Education Council Decisions of Northern Cyprus (1975-2014). http://egitimsurasi.mebnet.net/

[8] Documents of Minister of National Education and Culture (2016). http://www.mebnet.net 